\title{
Endoscopic Submucosal Dissection: Experience in Portugal
}

\author{
João Santos-Antunes Margarida Marques Guilherme Macedo \\ Gastroenterology Department, Centro Hospitalar S. João, Porto, Portugal
}

Keywords

Endoscopic submucosal dissection · Endoscopy

\section{Dissecção Endoscópica da Submucosa: Experiência em Portugal}

\section{Palavras Chave}

Dissecção endoscópica da submucosa · Endoscopia

\section{Dear Editor,}

We read with great interest the paper by Costa et al. [1] entitled "Endoscopic Submucosal Dissection for the Treatment of Superficial Epithelial Gastric Neoplasia in a Portuguese Centre".

Costa et al. reported their experience of 114 ESDs in gastric neoplastic lesions, with very good results. This is a very significant single-operator casuistic. In fact, at the time of the initial submission of the paper (November 2017), that was "the second largest Portuguese case series report published," as stated in the manuscript.

In his Editorial [2] published in the same issue, Baldaque-Silva made a description of the ESD panorama in Portugal, citing other published Portuguese ESD series $[3,4]$.

Besides those series cited by Costa et al. and BaldaqueSilva, Santos-Antunes et al. [5] published at the beginning of 2018 the initial experience of 301 ESDs performed between 2011 and May 2017 at the Gastroenterology De-

\section{KARGER}

E-Mail karger@karger.com www.karger.com/pjg (c) 2019 Sociedade Portuguesa de Gastrenterologia

Published by S. Karger AG, Basel

Karcer

Open access

This article is licensed under the Creative Commons AttributionNonCommercial-NoDerivatives 4.0 International License (CC BYNC-ND) (http://www.karger.com/Services/OpenAccessLicense). Usage and distribution for commercial purposes as well as any distribution of modified material requires written permission. partment of the Centro Hospitalar S. João, where we will probably achieve the 500th procedure during the current year.

In Portugal, we have overall published more than 600 ESDs in different centers, which represents the largest series in a single Western country. The outcome reported in all of these series is very good, in fact approaching in some cases the Eastern outcome. As Baldaque-Silva stated [2], the good results found in gastric ESD will lead to the implementation of esophageal and colorectal ESD. We absolutely agree, as this is already implemented in our hospital, where we had performed 118 colorectal and 10 esophageal ESDs since 2015. This is particularly true for the rectum, where we always perform ESD in large lesions in order to avoid a piecemeal resection in this topography.

As he also stated [2], the future is bright. It would certainly be brighter if the different institutions make an additional effort to work together, for example, in multicentric prospective studies. Since the beginning of the ESD practice in Portugal, we have now probably already surpassed 1,000 ESDs in all Portuguese centers. We all should be proud of this landmark and of the quality of endoscopy that is practiced in Portugal, and we must be recognized as a reference country regarding the ESD practice in Europe.

\section{Disclosure Statement}

The authors have no conflicts of interest to declare. 


\section{References}

1 Costa RS, Ferreira A, Leal T, Costa D, Rolanda C, Gonçalves R. Endoscopic Submucosal Dissection for the Treatment of Superficial Epithelial Gastric Neoplasia in a Portuguese Centre. GE Port J Gastroenterol. 2019 Mar;26(2): 90-8.Appendix after References (Editorial Comments)

2 Baldaque-Silva F. The East in the West. GE Port J Gastroenterol. 2019 Mar;26(2):81-2.
3 Rodrigues J, Carmo J, Carvalho L, Barreiro P, Chagas C. Endoscopic submucosal dissection for gastrointestinal superficial lesions: initial experience in a single Portuguese center. GE Port J Gastroenterol. 2015 Jul;22(5):190-7.

4 Libânio D, Pimentel-Nunes P, Afonso LP, Henrique R, Dinis-Ribeiro M. Long-term outcomes of gastric endoscopic submucosal dissection: focus on metachronous and noncurative resection management. GE Port J Gastroenterol. 2017 Jan;24(1):31-9.
5 Santos-Antunes J, Baldaque-Silva F, Marques M, Lopes J, Carneiro F, Macedo G. Real-life evaluation of the safety, efficacy and therapeutic outcomes of endoscopic submucosal dissection in a Western tertiary centre. United European Gastroenterol J. 2018 Jun;6(5):7029. 